\title{
Pulmonary choristoma in a new-born calf with multiple cranial and nervous malformations
}

\author{
Júlia Gabriela Wronski ${ }^{*}$ (D) Fernando Froner Argenta ${ }^{1}$ (D) Regina Tose Kemper $^{1}$ (D) \\ Jacqueline Raiter $^{1}$ (D) Natasha Rossoni de Oliveira ${ }^{1}$ (D) David Driemeier ${ }^{1}$ (D) \\ Saulo Petinatti Pavarini ${ }^{1}$ (D) Luciana Sonne ${ }^{1}$ (D)
}

${ }^{1}$ Setor de Patologia Veterinária, Universidade Federal do Rio Grande do Sul (UFRGS), 90540-000, Porto Alegre, RS, Brasil. E-mail: juliawronski@gmail.com. "Corresponding author.

ABSTRACT: Multiple congenital malformations can occur concomitantly in several species since the anomaly in one organ may lead directly to the malformation of another. Additionally, the etiology is not always clarified. Choristoma refers to an ectopic tissue that is histologically normal in an abnormal location. A case of pulmonary and nodal choristoma associated with cranioschisis, hydrocephalus, and syringomyelia in a new-born calf is reported here. Clinically, the calf had a mass in the frontal region of the head associated with local bone deformation. At necropsy, there was cranioschisis in the junction of the frontal bones and a $14 \times 10 \times 7 \mathrm{~cm}$ mass, grossly consistent with well-differentiated pulmonary tissue covered by skin, covering the opening between the frontal bones, and extending into the cranial cavity, leading to local cerebral compression. With the pulmonary choristoma, there was a well-differentiated lymphoid tissue. Additionally, in the central nervous system, there was severe hydrocephalus involving lateral ventricles and multiple areas of syringomyelia in the spinal cord.

Key words: bovine, choristoma, congenital malformation, hydrocephalus, syringomyelia.

\author{
Coristoma pulmonar em um bezerro recém-nascido com múltiplas \\ malformações cranianas e neurológicas
}

\begin{abstract}
RESUMO: Múltiplas malformações congênitas podem ocorrer concomitantemente em diversas espécies, uma vez que a anomalia em um órgão pode diretamente acarretar a malformação de outro. Ainda, a etiologia envolvida nem sempre é identificada. Coristomas são caracterizados por tecido ectópico histologicamente normal em uma localização anômala. Um caso de coristoma pulmonar e nodal associado a craniosquise, hidrocefalia e siringomielia em um bezerro recém-nascido é descrito neste trabalho. Clinicamente, o bezerro apresentava uma massa na região frontal da cabeça associada a deformação óssea local. No exame de necropsia, havia craniosquise na junção dos ossos frontais e tecido pulmonar bem diferenciado recoberto por pele, medindo $14 \times 10 \times 7 \mathrm{~cm}$, recobrindo a abertura entre os ossos frontais e adentrando a cavidade craniana, acarretando o achatamento do córtex cerebral adjacente. Juntamente com o tecido pulmonar, havia um nódulo composto por tecido linfoide bem diferenciado. Adicionalmente, no sistema nervoso central, havia hidrocefalia severa envolvendo os ventriculos laterais e múltiplas áreas de siringomielia na medula espinhal.
\end{abstract}

Palavras-chave: bovino, coristoma, malformações congênitas, hidrocefalia, siringomielia.

Congenital anomalies occur in all animal species and most of them are recognized during a clinical examination; although, the cause may be difficult to determine (MACÊDO et al., 2011; OLIVEIRA et al., 2011). Among the most frequent causes correlated with these malformations, are infectious agents, mainly viruses, and noninfectious causes, such as genetic disorders, toxins, and nutritional imbalances (MARCOLONGOPEREIRA et al., 2010; AGERHOLM et al., 2015). In Brazil, the frequency of congenital anomalies in cattle is estimated to be 0.2 to $3 \%$ (DANTAS et al., 2010; MARCOLONGO-PEREIRA et al., 2010; MACÊDO et al., 2011; OLIVEIRA et al., 2011).

Multiple congenital malformations can occur concurrently once there is an anomaly in one organ which may lead directly to the malformation of another(ISLAM et al., 2011), and the ability to identify and differentiate them individually is important in these cases of multiple alterations. Choristoma is a developmental alteration characterized by ectopic tissue that is histologically normal in an abnormal 
location (CHAUVET et al., 1994; BIANCHI et al., 2015). Conversely, hydrocephalus is characterized by abnormal accumulation of fluid in the cranial cavity, while cranioschisis is defined as failure in the fusion of cranial bones (CANTILE \& YOUSSEF, 2016). Finally, syringomyelia is defined as a fluidfilled cystic and tubular cavity named syrinx within the spinal cord and extending into several segments (BURGSTALLER et al., 2015). This report described a case of pulmonary and nodal choristoma associated with cranioschisis in a new-born bovine with hydrocephalus and syringomyelia.

A twelve-hour-old, female, Aberdeen Angus calf was presented to the Laboratory of Veterinary Pathology after being identified with a large frontal mass and inability to suckle. On clinical examination, a $10 \mathrm{~cm}$ mass was noticed in the region of the frontal bone, associated with deformation of the frontal and parietal bones (Figure 1). The calf had bilateral blindness, muscle stiffness, difficulty to keep standing, and unsteady gait. The tentative clinical diagnosis was cranioschisis with meningocele. Owing to poor prognosis, the animal was euthanized.
During the gross examination, an increase in volume of soft consistency was noticed dorsal to the frontal bones. The head was then opened through a longitudinal section in the median plane. On the cut section, the frontal and parietal bones were domeshaped and discontinuous (cranioschisis), and the opening was occupied by a subcutaneous, $14 \times 10 \times$ $7 \mathrm{~cm}$, multilobular mass covered by skin. The mass was covering the opening between frontal bones and extending into the cranial cavity, leading to compression of the brain associated with the region. The mass was pink, soft, and grossly compatible with lung parenchyma with white, firm, tubular structures compatible with bronchi (Figure 2). There was also a soft, well delimitated, $1 \mathrm{~cm}$ in diameter, round nodule adjacent to the mass, that was brown and soft on cut section, grossly compatible with lymphoid tissue (Figure 2, white arrow).

The cerebral lateral ventricles were markedly dilated and filled with a great amount of translucent serous liquid (cerebrospinal fluid; hydrocephalus); the remaining telencephalic cortex was 3 to $5 \mathrm{~mm}$ thick. There was flattening of the

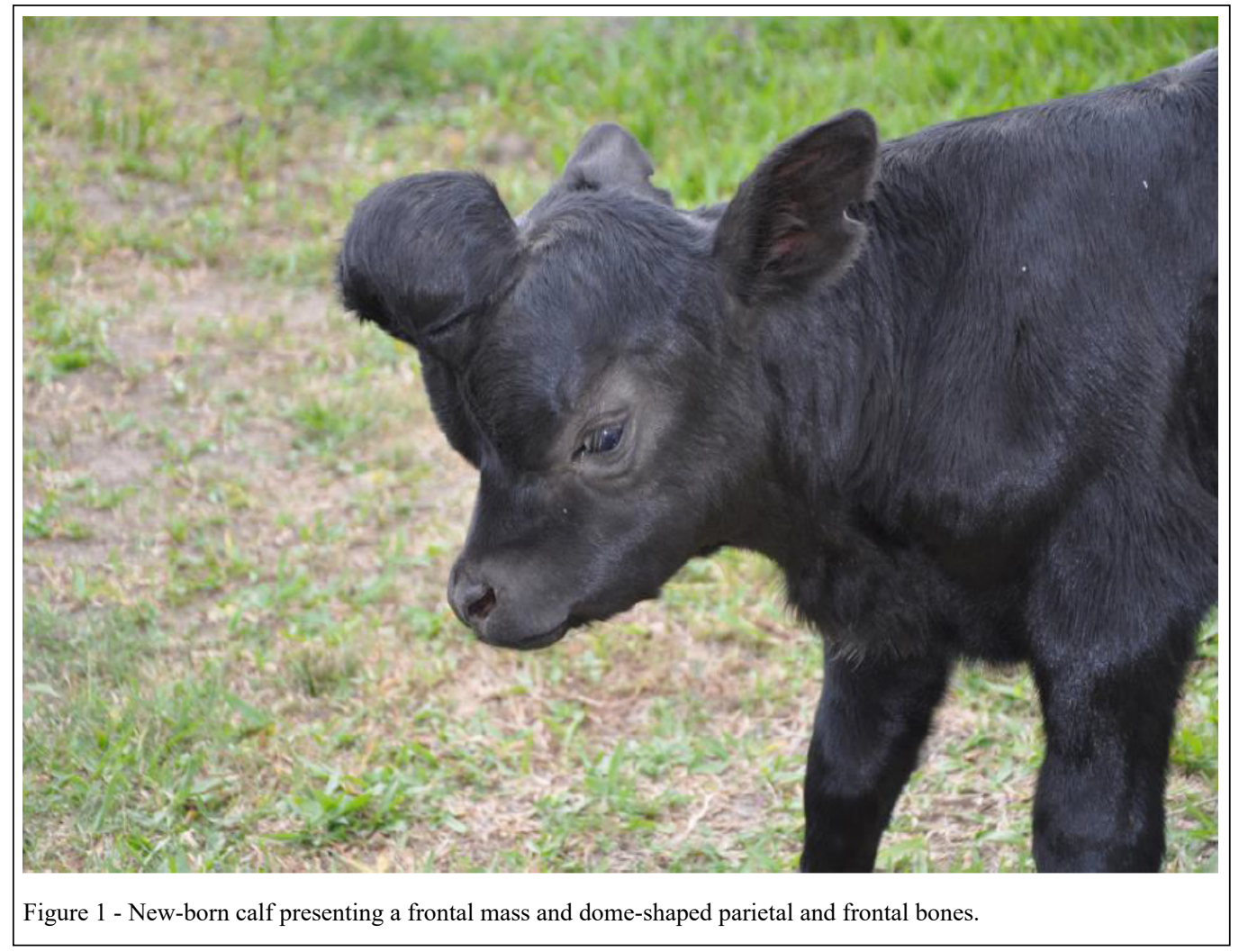

Ciência Rural, v.52, n.7, 2022. 


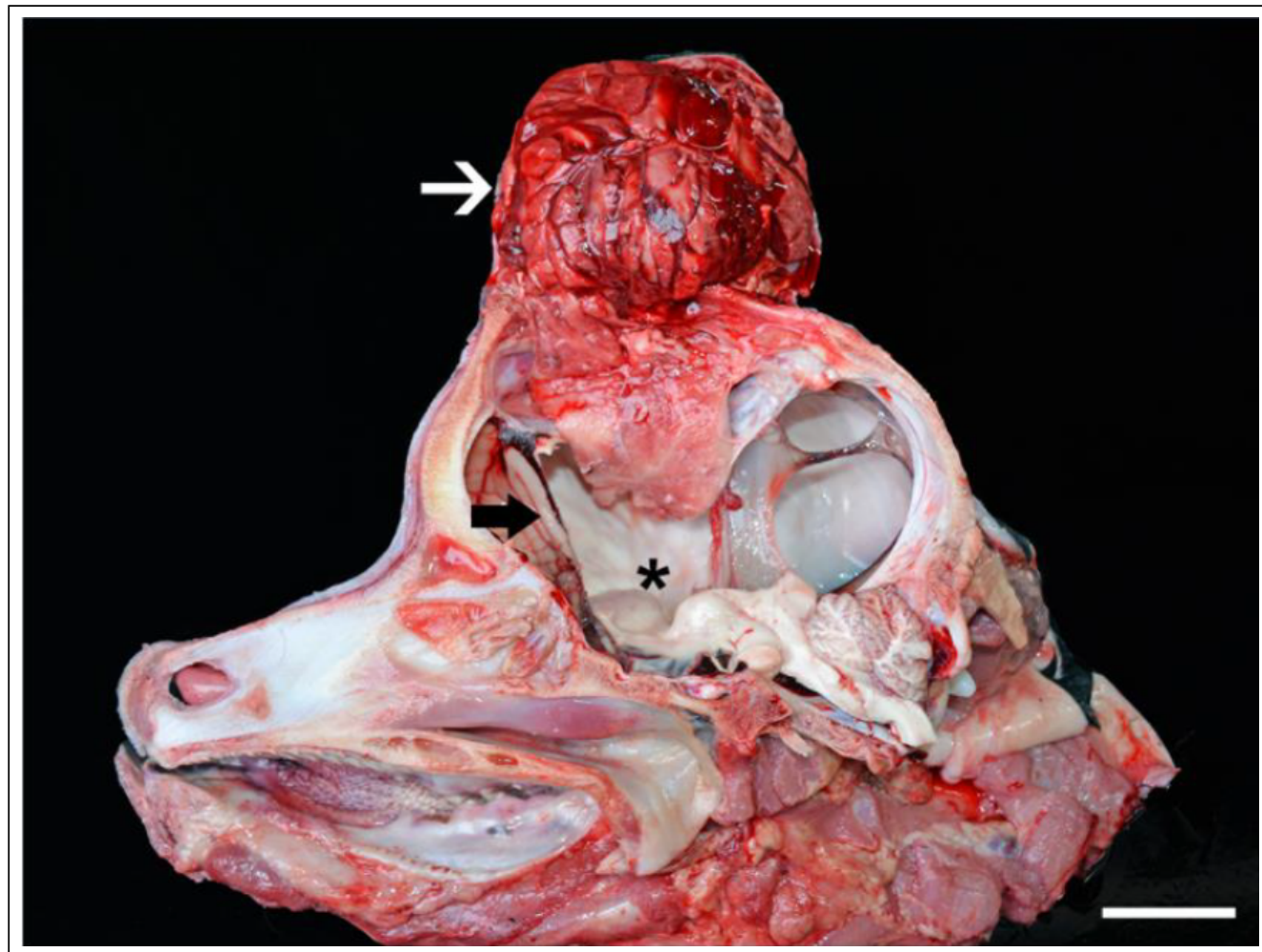

Figure 2 - Longitudinal section of the head. Note the cranioschisis associated with dome-shaped frontal and parietal bones, well-differentiated pulmonary tissue (white arrow) extending into the cranial cavity through the cranioschisis and compressing the thin cerebral cortex (black arrow), and severe hydrocephalus (asterisk). Bar $=4 \mathrm{~cm}$.

hippocampus, lack of the third ventricle, and nonfusion of the thalamus with separation of the thalamic antimeres by a central fissure. In addition, cystic areas of different sizes were noted in the gray and white matter of the cervical, thoracic, and sacral spinal cord, distorting but not involving the central spinal canal (Figure 3).

Fragments of multiple organs, including from the central nervous system (CNS) and the mass from the head, were collected in $10 \%$ neutral buffered formalin routinely processed for histopathological evaluation, and stained with hematoxylin and eosin. Additionally, fresh samples of CNS, liver, and whole blood were collected refrigerated, and sent to polymerase chain reaction (PCR) for bovine viral diarrhea virus (BVDV) (Weber et al., 2014).

Histologically, well-differentiated pulmonary tissue was noticed in the subcutaneous tissue and extending into the cranial cavity, characterized by numerous atelectatic alveoli, that were rarely filled with a discrete amount of an amorphous eosinophilic material (pulmonary choristoma) (Figure 4). Additionally, bronchi with cartilage, bronchioles, and distended and congested vessels were observed in the section. The pulmonary choristoma was covered by a thick fibrous pleura-like tissue. Extensive multifocal areas of hemorrhage, deposition of fibrin, and mild neutrophilic infiltrate were seen.

Adjacent to the pulmonary tissue, a well-differentiated lymphoid tissue with multiple lymphoid follicles, subcapsular and medullary sinus, and a capsule of connective tissue was observed (nodal choristoma). In the brain, pons, and thalamus, rarefaction of the nervous tissue was noticed, in addition to multifocal areas of hemorrhage in the meninges. In the spinal cord, syringomyelia was confirmed on light microscopy. PCR was performed and all samples were negative for BVDV. 


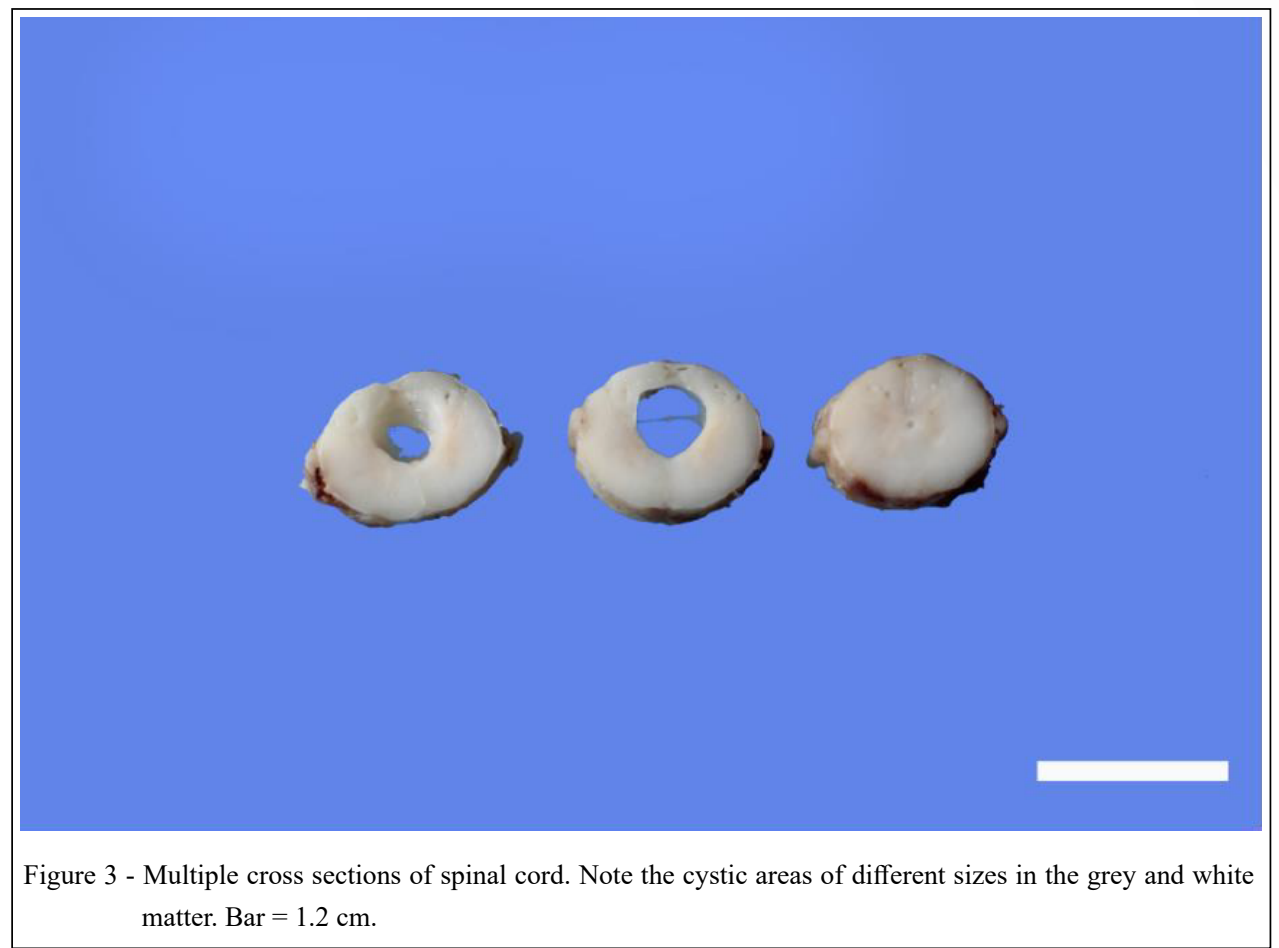

Pulmonary choristoma is characterized by ectopic pulmonary tissue histologically normal in an anomalous location, considered to be a malformation of the embryonic foregut. This alteration can occur occasionally in cattle, and it has been described in subcutaneous tissue, abdominal and thoracic cavities, and dorsal to the spinal cord (CHAUVET et al., 1994; CANPOLAT \& EROKSUZ, 2007; BASSI et al., 2010; ISLAM et al., 2011; OLIVEIRA et al., 2011; KILIÇ et al., 2015). In this case, grossly the pulmonary choristoma presented as a large mass in the subcutaneous tissue covered by skin and entering the cranial cavity through the cranioschisis in the frontal bone; and histologically it was composed of normal pulmonary structures.

Many theories have tried to explain the origin of this ectopic pulmonary tissue. The most accepted one suggested that alterations occur during embryogenesis and are considered malformations originated from the supranumeric embryonic pulmonary tissue, which develops caudal to the normal pulmonary tissue and migrates with the esophagus during development (CANPOLAT \& EROKSUZ, 2007; BASSI et al., 2010; ISLAM et al., 2011). Other authors believe that choristoma may originate from ectopic pluripotent cells, which then develop into respiratory tissue (CHAUVET et al., 1994; BASSI et al., 2010). A third hypothesis suggested that a supranumeric tracheobronchial tube originates directly from the embryonic primitive foregut cranial or caudal to the original site of the normal tracheobronchial tube (THOMSON, 1966; BASSI et al., 2010).

A case of pulmonary choristoma associated with meningocele was described in Northeast Brazil, and the authors attributed the process to mechanic action caused by the ectopic pulmonary tissue during fetal development, leading to a failure in fusioning the cranium and exposure of the meninges (OLIVEIRA et al., 2011). In the case here described, it is believed that, similarly, the ectopic pulmonary tissue contributed to the non-fusioning of the frontal bones, acting mechanically to prevent this process. Moreover, retrospective studies demonstrated the majority of cranioschisis cases are associated with other birth defects, among them hydrocephalus (MACÊDO et al., 2011), as observed in this case.

In contrast to previously reported cases (CHAUVET et al., 1994; OLIVEIRA et al., 2011), this animal showed severe neurological clinical signs, which led to the election for euthanasia. We believed the clinical signs in the calf here described were

Ciência Rural, v.52, n.7, 2022. 


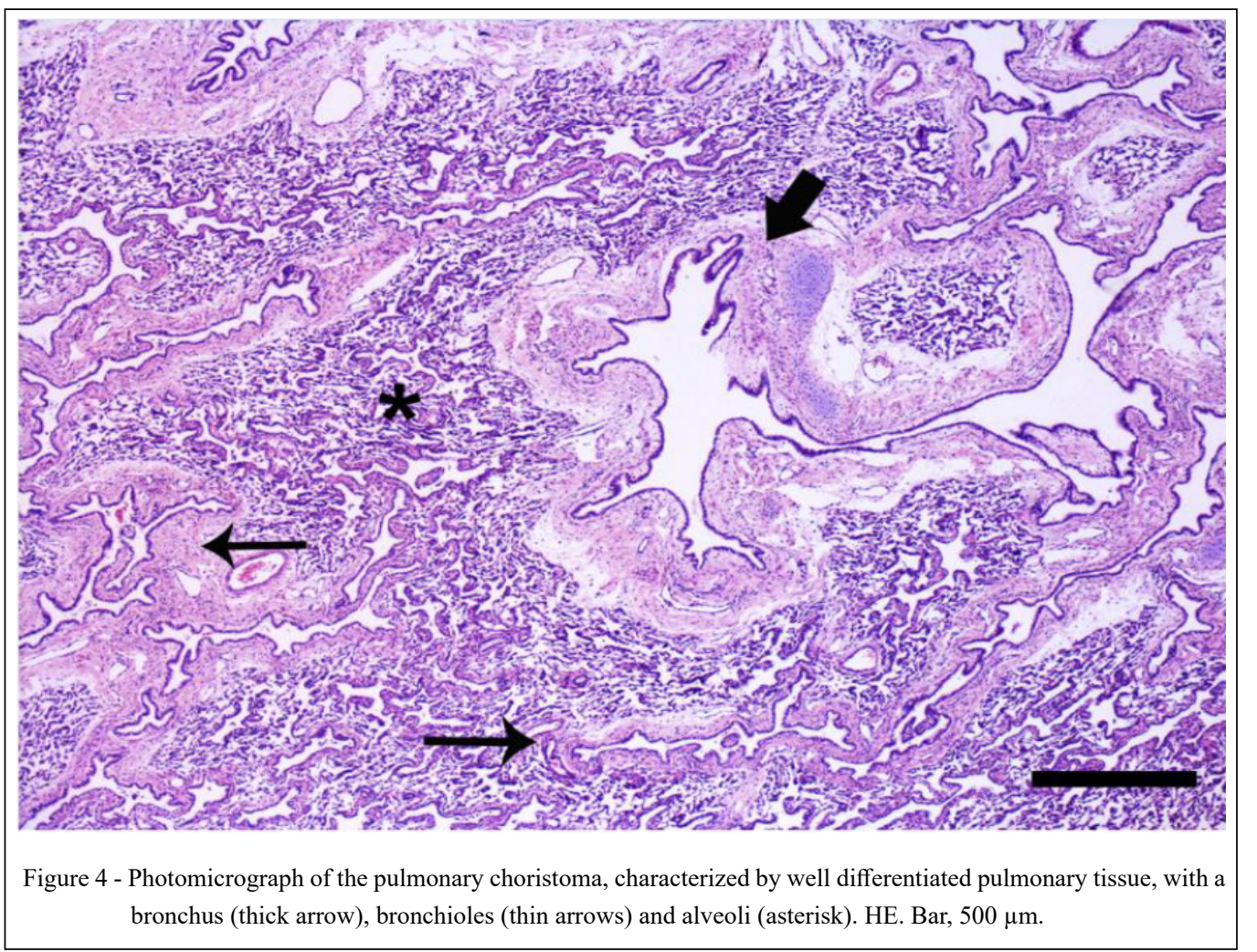

mainly related to hydrocephalus and syringomyelia. Although, the ectopic pulmonary tissue might have contributed to the development of the condition, we believe this was not associated with the clinical signs of this calf, since multiple congenital malformations are frequently noticed but not necessarily correlated with the clinical presentation (MACÊDO et al., 2011).

In addition to the pulmonary choristoma, the calf in this study also presented an ectopic lymphoid tissue associated with the ectopic respiratory tissue. The lymph nodes are secondary lymphoid organs, and it is believed that their development is discontinued after birth; however, lymphoid neogenesis can develop in sites of chronic inflammation or infectious processes even after birth (DRAYTON et al., 2006; CLANCY et al., 2018). As a result, we hypothesized that the ectopic lymph node associated with pulmonary choristoma, in this case, is an ectopic tissue as the pulmonary choristoma since no chronic inflammation was seen.

Clinically, the animal in this report was diagnosed with meningocele, and only after the necropsy examination, it was possible to determine the nature of the protuberance in the frontal bone. Cranial meningocele, contrary to the calf here reported, consists of protrusion of the meninges through the defective cranium, giving rise to a sacculation filled with CSF and covered by skin and can also involve nervous tissue (meningoencephalocele). As a result, the neurological signs depend on the degree of central nervous system involvement (SUMMERS et al., 1995; OLIVEIRA et al., 2011). Another possible clinical differential is lipomeningocele, which consisted of a pedunculated mass of adipose tissue covered by skin that enters in the cranium through the cranioschisis and that can also involve the spinal canal; yet it does not show clinical signs when there is no involvement of nervous tissue (GOPAL \& LEIPOLD, 1979; SUMMERS et al., 1995).

Anomalies in the CNS are among the congenital defects most seen in domestics animals, mainly due to its high level of differentiation and complexity (MACÊDO et al., 2011). The most frequent causes attributed to malformation in this anatomic location include infectious agents, mainly viruses, and non-infectious, such as genetic 
disorders, toxins, and nutritional imbalances. Among the teratogenic viruses distributed worldwide of importance in ruminant medicine, are BVDV, Schmallenberg virus, Bluetongue virus, Akabane virus, Border diseases virus, and Aino virus. These can cause hydranencephaly, porencephaly, hydrocephalus, microcephaly, cerebellar hypoplasia, among other anomalies (AGERHOLM et al., 2015). However, similar to this case, the cause of the congenital defect cannot always be determined (MACÊDO et al., 2011; AGERHOLM et al., 2015; CANTILE \& YOUSSEF, 2016). At the time of preparation of this report, no other cases of birth defects were documented in the same farm, though a hereditary component cannot be excluded.

While the etiology in this present case was not clarified, several genetic, infectious, and environmental factors may have contributed to the development of the congenital anomaly. To the authors' knowledge, this is the first report of pulmonary and nodal choristoma, hydrocephalus, and syringomyelia associated with marked neurologic clinical signs in cattle. Although rare, these lesions should be included among the differential diagnosis for neonatal calf with neurologic signs and increased in the cranial region.

\section{ACKNOWLEDGEMENTS}

We thank Conselho Nacional de Desenvolvimento Científico e Tecnológico (CNPq) and Coordenação de Aperfeiçoamento de Pessoal de Nível Superior (CAPES) for financial support.

\section{BIOETHICS AND BIOSSECURITY COMMITTEE APPROVAL DECLARATION}

We authors of the article entitled " Pulmonary and nodal choristoma associated with cranioschisis in a new-born calf with hydrocephalus and syringomyelia" declared, for all due purposes, the project that gave rise to the present data of the same has not been submitted for evaluation to the Ethics Committee of the University "Universidade Federal do Rio Grande do Sul", but we are aware of the content of the Brazilian resolutions of the National Council for Control of Animal Experimentation CONCEA "http://www.mct.gov.br/index.php/content/ view/310553.html" if it involves animals. Thus, the authors assume full responsibility for the presented data and are available for possible questions, should they be required by the competent authorities.

\section{DECLARATION OF CONFLICT OF INTEREST}

We have no conflict of interest to declare with respect to the research, authorship and/or publication of this article.

\section{AUTHORS' CONTRIBUTIONS}

All authors contributed equally for the conception and writing of the manuscript. All authors critically revised the manuscript and approved of the final version

\section{REFERENCES}

AGERHOLM, J.S. et al. Virus-induced congenital malformations in cattle. Acta Veterinaria Scandinavica, v. 57, n.54, p. 1-14, 2015. Available from: <https://pubmed.ncbi.nlm.nih.gov/26399846/>. Accessed: Jun. 17, 2020. DOI: 10.1186/s13028-015-0145-8.

BASSI, P. et al. Retroperitoneal pulmonary choristoma in a newborn calf. Journal of veterinary diagnostic investigation, v. 22 , n. 6 , p. $1008-1010,2010$. Available from: <https://journals. sagepub.com/doi/full/10.1177/104063871002200631>. Acessed: Feb. 15, 2021. DOI: <https://doi.org/10.1177/10406387100220 $0631>$.

BIANCHI, M.V. et al. Collagenous choristoma at the cerebellar peduncle of a Nelore bull. Semina: Ciências Agrárias, v. 36, n. 1, p. 2037-2040, 2015. Available from: <https://www.redalyc. org/pdf/4457/445744149048.pdf>. Acessed: Jun. 20, 2020. DOI: 10.5433/1679-0359.2015v36n3Supl1p2037.

BURGSTALLER, J. et al. Syringomyelia in a newborn male Simmental calf. Journal of Veterinary Internal Medicine, v. 29, n. 6, p. 1633, 2015. Available from: <https://www.ncbi.nlm.nih. gov/pmc/articles/PMC4895670/> . Accessed: Jun. 18, 2020. DOI: $10.1111 /$ jvim. 13646 .

CANPOLAT, I.; ERÖKSÜZ, Y. Pulmonary sequestration and bronchogenic cyst in a calf. Firat Üniversitesi Saglik Bilimleri Dergisi, v. 21, n. 6, p. 281-284, 2007. Available from: <http:// veteriner.fusabil.org/pdf/pdf_FUSABIL_545.pdf $>$. Accessed: Jun. $18,2020$.

CANTILE, C. \& YOUSSEF, S. Nervous System. In: MG Maxie (ed). Jubb, Kennedy and Palmer's Pathology of Domestic Animals. St. Louis: Elsevier Publisher, 2016, v. 1, pp. 250-406.

CHAUVET, A.E. et al. Pulmonary choristoma in a calf. The Canadian Veterinary Journal, v. 35, n. 7, p. 441, 1994. Available from: <https://www.ncbi.nlm.nih.gov/pmc/articles/ PMC1686262/>. Accessed: Jun. 20, 2020.

CLANCY, C.S. et al. Intracranial, extraneural ectopic lymph node in a bovine (Bos taurus). Anatomia, histologia, embryologia, v. 47, n. 4, p. 385-388, 2018. Available from: <https://onlinelibrary. wiley.com/doi/abs/10.1111/ahe.12364>. Accessed: Jun. 20, 2020. DOI: <https://doi.org/10.1111/ahe.12364>.

DANTAS, A.F.M. et al. Congenital malformations in ruminants in the semiarid of the Brazilian Northeast. Pesquisa Veterinária Brasileira, v. 30 , n. 10 , p. $807-$ 815, 2010. Available from: <https://www.scielo.br/scielo. php?pid $=$ S0100-736X2010001000002\&script $=$ sci arttext $>$. Accessed: Jun. 17, 2020. DOI: <https://doi.org/10.1590/S0100736X2010001000002>.

DRAYTON, D.L. et al. Lymphoid organ development: from ontogeny to neogenesis. Nature immunology, v. 7, n. 4, p. 344353, 2006. Available from: <https://www.nature.com/articles/ ni1330>. Accessed: Jun. 15, 2020. 
GOPAL, T. \& LEIPOLD, H.W. Lipomeningocele in a calf. Veterinary pathology, v. 16, n. 5, p. 610-612, 1979. Available from: <https://journals.sagepub.com/doi/pdf/10.1177/0300985879 01600515>. Accessed: Jun. 20, 2020

ISLAM, M.R. et al. Multiple congenital anomalies in a Korean native calf (Bos taurus coreanae). Korean Journal of Veterinary Research, v. 51, n. 1, p. 63-67, 2011. Available from: <https:// www.koreascience.or.kr/article/JAKO201125965027762. page>. Accessed: Jun. 18, 2020. DOI: <https://doi.org/10.14405/ kjvr.2011.51.1.063>.

KILIÇ, E. et al. Subcutaneous ectopic lung in the cervical region of a calf. Veterinarski arhiv, v. 85, n. 6, p. 701-709, 2015. Available from: <http://intranet.vef.hr/vetarhiv/papers/2015-85-6-10.pdf>. Accessed: Jun. 18, 2020.

MACÊDO, J.T.S.A. et al. 2011. Defeitos congênitos em bovinos da Região Central do Rio Grande do Sul. Pesquisa Veterinária Brasileira, v. 31, n. 4, p. 297-306, 2011. Available from: $\quad<$ https://www.scielo.br/pdf/pvb/v31n4/a05v31n4.pdf $>$. Accessed: Jun. 17, 2020. DOI: <https://doi.org/10.1590/S0100736X2011000400005>

MARCOLONGO-PEREIRA, C. Defeitos congênitos diagnosticados em ruminantes na Região Sul do Rio Grande do Sul. Pesquisa Veterinária Brasileira, v. 30 , n. 10, p. 816-826,
2010. Available from: <https://www.scielo.br/pdf/pvb/v30n10/ a14v30n10.pdf $>$. Accessed: Jun. 21, 2020. DOI: <http://dx.doi. org/10.1590/S0100-736X2010001000003>.

OLIVEIRA, P. et al. Retrospective review of congenital heart disease in 976 dogs. Journal of veterinary internal medicine, v. 25 , n. 3, p. 477-483, 2011. Available from: $<$ https:// onlinelibrary.wiley.com/doi/full/10.1111/j.1939-1676.2011.0711. $\mathrm{x}>$. Accessed: Jul. 1, 2020. DOI: <https://doi.org/10.1111 /j.1939-1676.2011.0711.x>

SUMMERS B.A. et al. Malformations of the central nervous system. In: SUMMERS, B.A. et al. (ed). Veterinary Neuropathology. St. Louis: Mosby Publisher, 1995, pp. 68-94

THOMSON, R.G. Congenital bronchial hypoplasia in calves. Pathologia veterinaria, v. 3, n. 2, p. 89-109, 1966. Available from: $<$ https://journals.sagepub.com/doi/abs/10.1177/030098586600300 201>. Accessed: Jun. 18, 2020. DOI: < https://doi.org/10.1177/03 $0098586600300201>$.

WEBER, M.N. et al. High frequency of bovine viral diarrhea virus type 2 in Southern Brazil. Virus research, v. 191, p. 117-124, 2014. Available from: <https://www.sciencedirect.

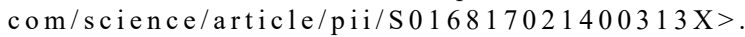
Accessed: Jun. 15, 2020. DOI: <https://doi.org/10.1016/j. virusres.2014.07.035>. 